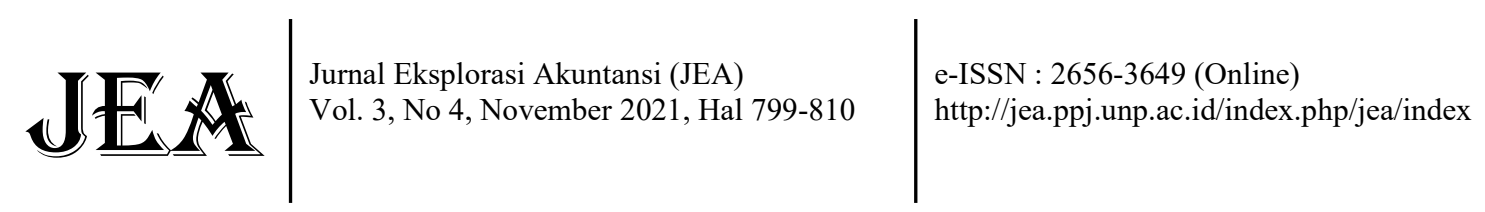

\title{
Analisa Konstruksi Sosial Implementasi Akuntansi Keuangan Untuk Usaha Mikro, Kecil dan Menengah
}

\author{
Ade Palupi ${ }^{1 *}$, Nada Salsabila ${ }^{2}$ \\ 1,2 Universitas Al-Azhar Indonesia \\ *Korespondensi: ade.palupi@uai.ac.id
}

\begin{abstract}
This research takes the lens that the implementation of accounting in micro, small and medium enterprises (MSMEs) into social construction uses a theoretical framework that reviews accounting from the context of its implementation (Hopwood, 2013). The purpose of this research is to prove that accounting practices are the result of mutual relationships between accounting, organizations and institutions, especially in accounting practices in MSMEs. The research approach uses qualitative methods by interviewing fifteen MSME business actors spread across Java and Kalimantan. The results of this study concluded that the interaction of accounting institutions and social factors in the implementation of accounting in MSMEs has not been dynamic and optimal. However, accounting institutions in MSMEs have been formed pragmatically but yet normatively because its implementation has not been conformed to SAK EMKM. Currently MSMEs apply accounting in accordance with their knowledge capacity and abilities that are tailored to their business condition. Nevertheless, the benefits of the application of accounting are experienced and MSME business actors believe that accounting can bring economic and social benefits to the development of their business in future.
\end{abstract}

Keywords: Accounting for MSMEs; MSM; Hopwood.

How to cite (APA $6^{\text {th }}$ style)

Palupi, Ade \& Salsabila, Nada. (2021). Analisa Konstruksi Sosial Implementasi Akuntansi Keuangan Untuk Usaha Mikro, Kecil dan Menengah. Jurnal Eksplorasi Akuntansi (JEA), 3 (4), 799-810

\section{PENDAHULUAN}

Penelitian ini bertujuan untuk membangun pemikiran bahwa keberhasilan implementasi akuntansi adalah hasil dari interaksi institusi akuntansi dengan lingkungan sosialnya, yang dalam studi ini meneliti bagaimana standar akuntansi diaplikasikan atau tidak oleh pengusaha Usaha Mikro, Kecil dan Menengah (UMKM). Kerangka teori yang digunakan penelitian ini adalah pemahaman pelaksanaan akuntansi yang ditinjau dari konsep pemikiran Hopwood (2013) yang mampu memberikan pemahaman bahwa berhasil atau tidaknya implementasi akuntansi adalah karena interkasi dari aspek teknik dan aspek sosial dimana akuntansi dipraktikkan. Konsep ini tepat digunakan untuk menjelaskan bagaimana suatu entitas mengaplikasikan akuntansi pada saat awal-awal pelaksanaannya. Manfaat 
penelitian diharapkan memberikan bahan kajian untuk mendorong implementasi akuntansi di kalangan UMKM.

Laporan OECD (2017) menjelaskan UMKM berperan penting dalam meningkatkan pertumbuhan ekonomi yang berkelanjutan dan inklusif. Untuk UMKM harus mempunyai tiga kemampuan yaitu compete, connect dan change dan agar bisa berkompetisi, UMKM harus mempunyai manajemen persediaan yang baik, catatan akuntansi yang komplit dan akun bank (International Trade Centre, 2021).

Perkembangan UMKM di Indonesia mengalami kenaikan yang signifikan. Laporan Kementerian Koperasi dan UKM RI, pada tahun 2017 menunjukkan jumlah unit UMKM sebesar 62.9 juta unit dan mencapai sekitar 64 juta per Maret 2021. Industri UMKM juga menyumbang pendapatan domestrik bruto pada tahun 2017 sebesar $60 \%$ dan naik menjadi 61\% pada 2021(Kementerian Keuangan Republik, 2021; Kementerian Koperasi dan UMKM, 2017). Propinsi DKI Jaya sebagai ibukota mempunyai indeks produksi untuk UMKM yang cukup tinggi yaitu 234, sedangkan propinsi Jawa Barat mempunyai indeks yang paling rendah se pulau Jawa yaitu diangka 125 pada tahun 2018. Sedangkan indeks produktivitas UMKM yang paling tinggi se-Indonesia adalah Gorontalo dengan angka sebesar 166 di tahun 2018 (Badan Pusat Statistik, 2019). Berdasarkan dua fenomena diatas, maka studi tentang bagaimana implementasi akuntansi di UMKM Indonesia penting dilakukan.

Hasil penelitian terdahulu menunjukkan bahwa realitas tentang implementasi akuntansi di UMKM di beberapa negara adalah sebagai berikut; (1) standar akuntansi untuk UMKM sudah ada di beberapa negara di kawasan ASEAN (Mizunoura 2015); (2) praktik akuntansi di UMKM belum sepenuhnya sesuai dengan standar akuntansi yang berlaku (Purwati, Suparlinah, and Putri 2014; Sibanda and Manda 2016); (3) ketidakmampuan pelaku UMKM dalam ilmu dan ketrampilan akuntansi menyebabkan mereka tidak mampu menyusun laporan keuangan berdasarkan standar akuntansi (Nwobu, Faboyede, and Onwuelingo 2015; Pulakanam and Suraweera 2010; Sibanda and Manda 2016); (4) informasi akuntansi berperan dalam menjaga kelangsungan bisnis UMKM (Ibarra and Velasco 2015; Kurniawati and Meilianaintani 2016; Purwati et al. 2014; Yanto et al. 2017).

Sedangkan hasil penelitian terdahulu tentang implementasi akuntansi di UMKM Indonesia menunjukkan bahwa banyak UMKM menghadapi kendala dalam penyusunan laporan keuangan. Kendala tersebut adalah (1) kurangnya pendidikan di bidang bisnis dan akuntansi; (2) kurangnya pemahaman akan teknologi informasi; dan (3) penggiat UMKM lebih mengutamakan faktor penjualan daripada akuntansi (Kurniawati, Nugroho, and Arifin 2012; Niode 2009; Savitri and Saifudin 2018).

Namun, penelitian-penelitian tersebut di atas hanya fokus pada teknik akuntansi yang dipraktikkan di UMKM dan belum menunjukkan bagaimana UMKM mengenal, memahami dan mampu menyusun laporan keuangan berdasarkan peraturan akuntansi yang berlaku. Oleh sebab itu, penelitian ini akan mengisi peluang tema tersebut dengan mengambil rumusan masalah bagaimana dinamika interaksi institusi dan sosial atas implementasi akuntansi dengan mengambil studi kasus di beberapa UMKM di Indonesia. Penelitian ini penting dilakukan untuk mengindentifikasi faktor apa saja yang menghalangi atau mempermudah UMKM dalam mengaplikasikan akuntansi sehingga mereka mampu meningkatkan kompetisinya.

Penelitian ini tidak bertujuan untuk mengeneralisasi pelaksanaan akuntansi di UMKM di Indonesia, namun penelitian ini berusaha menghasilkan suatu konstruksi pemikiran bahwa penerapan akuntansi di UMKM merupakan bentuk interaksi antara instutusi akuntansi dengan lingkungan sosialnya. Hal ini sesuai dengan konsep pemikiran Hines (1989) yang memandang bagaimana cara masyarakat berpikir, bertindak, terstruktur dan apa yang menurut masyarakat rasional dan obyektif merupakan hasil intepretasi atas apa yang terjadi di sekeliling mereka. Metode penelitian kualitatif dengan pendekatan studi kasus digunakan 
pada penelitian ini dengan menggunakan konsep pemikiran Hopwood (2013) sebagai kerangka teorinya.

\section{REVIU LITERATUR}

Konsep pemikiran Hopwood ( 2013) diterjemahkan oleh Chapman et al. (2010) dan Potter (2005) yang menyatakan bahwa kesuksesan penerapan akuntansi merupakan hasil dari interaksi antara faktor perhitungan dan pencatatan transaksi yang sesuai dengan peraturan akuntansi yang ada dan faktor sosial organisasi dan masyarakat yang melingkupi praktek akuntansi tersebut. Interaksi kedua faktor tersebut diartikan sebagai berikut; kesuksesan penerapan teknik akuntansi yaitu penguasaan mekanisme penilaian dan pencatatan transaksi ekonomi akan dipengaruhi oleh lingkungan sosial dimana pelaku praktik akuntansi tersebut berada. Ketika praktik akuntansi tersebut telah bisa dikuasai oleh pelaku akuntansi dan membawa dampak positif, hasil praktek akuntansi tersebut keluar ke masyarakat umum. Selanjutnya, masyarakat bersedia dan tunduk menerima hasil tersebut.

Chapman et al. (2010) menegaskan bahwa praktik akuntansi tergantung pada lingkungan institusionalnya yaitu struktur, peraturan, prosedur, sistem, formula yang membentuk satu set teknik bagaimana akuntansi diterapkan. Dengan adanya institusi yang merupakan aturan normatif bagaimana akuntansi diterapkan membawa kepada tingkatan alasan rasional mengapa praktik akuntansi diterapkan oleh individu atau organisasi (Burchell et al. 2013). Namun, penerapan satu set teknik tersebut dapat menjadi mitos karena hanya digunakan untuk seremonial saja atau bisa membawa perubahan di masyarakat sesuai dengan rasionalitas akuntansi (DiMaggio and Powell 1983; Hines 1989).

Selain faktor institusi, mengikuti pemikiran Hopwood (2013), praktik akuntansi juga tergantung dari faktor sosial. Burchell et al. (2013) menyatakan bahwa praktik akuntansi juga ditentukan oleh, seperti halnya, lingkungan organisasi dan manajemen (contoh: komitmen, kemampuan, ketersediaan dana), ketidakpastian lingkungan organisasi, strategi manajemen, dorongan pihak luar (contoh organisasi profesi dan pemerintah) dan lingkungan politik dan ekonomi.

Dengan demikian, akuntansi berperan mengubah cara pandang individu atau organisasi dalam mempertanggungjawabkan keuangan (Chapman et al. 2010). Keberhasilan interaksi faktor institusi dan sosial dalam implementasi akuntansi membawa dampak bahwa produk akuntansi berupa laporan keuangan digunakan oleh pengguna laporan untuk menentukan keputusan ekonomi seperti: (1) menghitung jumlah pajak terhutang; (2) memutuskan pendanaan; (3) melakukan ekspansi pasar atau produk.

Penelitian akuntansi dengan lensa dinamika interaksi sosial dan institutional ini membantu memahami bagaimana organisasi atau individu mengimplementasikan akuntansi. Kesuksesan institusi akuntansi dilaksanakan tergantung secara sosial dari lingkungan organisasi, perilaku dan pikiran organisasi atau individu. Institusionalisasi akuntansi akan berhasil jika dapat membentuk atau mengubah masyarakat untuk berpikir sesuai dengan rasionalitas akuntansi.

Berdasarkan konsep pemikiran institusionalisasi akuntansi hasil penelitian terdahulu, maka penelitian ini akan mencari bagaimana dinamika interaksi institusi dan faktor sosial dalam melaksanakan akuntansi di UMKM yang digunakan sebagai studi kasus. Bagian selanjutnya dalam artikel ini menjelaskan metode penelitian dan UMKM apa saja yang dijadikan studi kasus.

\section{METODE PENELITIAN}

Penelitian ini menggunakan pendekatan kualitatif, karena penelitian ini tidak mencari hubungan yang saling mempengaruhi antara variable. Oleh karena rumusan masalah penelitian ini adalah bagaimana bagaimana dinamika interaksi institusi dan sosial atas 
implementasi akuntansi di beberapa UMKM di Indonesia yang dijadikan studi kasus pada penelitian ini, maka metode penelitian yang digunakan adalah studi kasus (Yin 2015). Kasus yang diambil pada studi ini diambil secara acak dengan tidak melihat apakah UMKM tersebut mampu atau tidak mampu dalam melaksanakan akuntansi. Studi ini menggunakan metode studi kasus eksploratoris, karena fokus pada apa yang benar-benar terjadi atas interaksi institusi dan sosial sehingga UMKM dapat atau tidak dapat mengimplementasikan akuntansi untuk menyusun laporan keuangan sesuai dengan standar akuntansi (Pietkiewicz and Smith 2014; Yin 2015).

Data diambil dengan cara dokumentasi dan wawancara. Pencarian dokumen berupa perundangan dan peraturan terkait diberlakukannya akuntansi untuk UMKM di Indonesia dilakukan melalui Google. Dokumen digunakan untuk mendapatkan realitas dan rasionalitas institusi akuntansi yang mendasari praktik akuntansi untuk UMKM di Indonesia. Wawancara dilakukan dengan memakai media Zoom dan Video Call pada tahun 2020. Narasumber wawancara tersebar di lima propinsi yaitu sembilan dari DKI Jakarta, tiga dari Jawa Barat, satu dari DI Yogjakarta, satu dari Jawa Timur, dan satu dari Kalimantan TengahPemilihan daerah asal narasumber didapat secara acak, karena narasumber didapat dengan metode snowball. Tidak ada tujuan khusus untuk memilih kelima daerah tersebut.

Triangulasi data dan sumber data dimulai pada saat pemilihan narasumber. Pertama kali, narasumber didapat melalui komunitas UMKM di propinsi DKI Jaya dan Jawa Barat. Kemudian dua narasumber ini merekomendasikan ke narasumber lainnya yang termasuk dalam komunitas mereka sehingga didapat limabelas narasumber dari berbagai propinsi. Faktor keberagaman latar belakang narasumber yaitu, keberagaman daerah, latar belakang pendidikan narasumber, yaitu sarjana ekonomi/akuntansi, sarjana non ekonomi/akuntansi dan latar belakang pekerjaan utama masa lalu mereka dan bahkan pekerjaan mereka saat ini sebagai professional, pegawai negeri, ibu rumah tangga dan fresh graduate, menambah kekayaan data yang diperoleh. Triangulasi data dicapai sampai dengan mengerucutnya pandangan narasumber terhadap praktik akuntansi dengan mempertimbangkan latar belakang sosial mereka.

Wawancara dilakukan dengan metode semi-struktur agar lebih fleksibel dalam pencarian data. Triangulasi teori dilakukan dengan cara menyusun sistematika daftar pertanyaan wawancara sejalan dengan konsep Hopwood (2013) tentang bagaimana pengalaman narasumber dalam hal mengetahui, memahami dan menerapkan praktik akuntansi.

Hasil pencarian data melalui dokumen dan wawancara kemudian diolah dan dianalisis dengan kerangka teori dan hasil penelitian terdahulu. Analisis data menggunakan pendekatan analisis konstruktif karena penelitian ini bertujuan mengkonstruksikan pemikiran bagaimana interaksi institusi dan faktor sosial dalam usaha UMKM dalam mempraktikkan akuntansi. Hal ini sesuai dengan pemahaman analisa konstruktif yang dinyatakan oleh Kasanen \& Lukka (1993).

\section{HASIL DAN PEMBAHASAN}

Pemerintah Indonesia sudah mengakui secara politik, hukum dan sosial atas keberadaan UMKM sebagai bagian dari kesatuan perekonomian nasional. Pengakuan legalitas UMKM dimulai dari berubahnya nama lembaga pemerintah Departemen Koperasi menjadi Departemen Koperasi dan Pembinaan Pengusaha Kecil melalui Keppres Nomor 58 Tahun 1993 (Pemerintah Republik Indonesia, 1993) dan kemudian posisi UMKM diperkuat dengan ditetapkannya peran UMKM sebagai salah satu bagian dari struktur perekonomian nasional melalui Undang Undang No. 9 Tahun 1995 Tentang: Usaha Kecil (Pemerintah Republik Indonesia, 1995). Selanjutnya peran UMKM dalam struktur perekonomian nasional diatur dalam Ketetapan Majelis Permusyawaratan Rakyat Republik Indonesia Nomor 
XVI/MPR/1998, yang menyatakan negara bertanggungjawab dalam menciptakan struktur ekonomi nasional melalui hubungan kemitraan antara pengusaha menengah, kecil dan koperasi dengan usaha besar dan Badan Usaha Milik Negara (Pemerintah Republik Indonesia, 1998).

Kebijakan strategis pertumbuhan UMKM di Indonesia kemudian diatur di UndangUndang Republik Indonesia Nomor 20 Tahun 2008 Tentang Usaha Mikro, Kecil, Dan Menengah. Undang-undang ini mengamanahkan Pemerintah dan Pemerintah Daerah untuk menumbuhkan iklim usaha mikro, kecil dan menengah melalui kebijakan pendanaan, sarana dan prasarana, informasi usaha, kemitraan, perizinan usaha, kesempatan berusaha, promosi dagang, dan dukungan kelembagaan (Pemerintah Republik Indonesia, 2008).

Berdasarkan perundangan tersebut diatas, maka posisi UMKM secara politik dan hukum sudah kuat ditambah dengan kebijakan strategis dari pemerintah. Namun, dalam peraturan perundangan tersebut belum menngatur secara langsung tentang peran akuntansi untuk menyusun laporan keuangan UMKM.

Walaupun dalam peraturan hukum tidak disebutkan secara langsung peran akuntansi pada UMKM, Ikatan Akuntan Indonesia (IAI) sebagai organisasi profesi akuntan di Indonesia mengambil langkah mengatur praktik akuntansi di sektor UMKM. Dewan Standar Akuntansi Keuangan (DSAK) IAI menyusun Standar Akuntansi Keuangan Entitas Mikro, Kecil, dan Menengah (SAK EMKM), yang mulai berlaku efektif tanggal 1 Januari 2018. SAK EMKM diharapkan dapat menjadi salah satu pendorong literasi keuangan bagi UMKM di Indonesia sehingga mereka muda mengakses pembiayaan dari industri perbankan. (Ikatan Akuntan Indonesia n.d.).

Berdasarkan SAK EMKM, laporan keuangan yang harus disusun oleh UMKM terdiri dari laporan posisi keuangan, laporan laba rugi dan catatan atas laporan keuangan. Sedangkan basis pengukuran yang digunakan adalah biaya historis.

Pembahasan selanjutnya adalah bagaimana UMKM memahami dan melaksanakan praktik akuntansi yang sesuai dengan peraturan yang berlaku. Penelitian ini mengambil limabelas pebisnis UMKM untuk diwawancarai.

Profil narasumber adalah sebagai berikut (1) Y mempunyai usaha penyedap rasa; (2) S seorang pegawai yang mempunyai bisnis makanan kecil; (3) NM adalah ibu rumah tangga yang juga sebagai wirausaha pakaian tradisional; (4) DA yang mengelola usaha keluarga batik; (5) LG seorang wirausaha snack; (6) D pemilik usaha kedai kopi; (7) ST pemilik toko bangunan; (8) A pemilik toko meubel; (9) SH seorang wirausaha kerajinan tangan; (10) YD seorang wirausaha kuliner; (11) RB pemilik dan pengelola usaha barbershop; (12) NC memiliki usaha konveksi pakaian; (13) YE memiliki usaha kerajinan tas; (14) RV seorang professional dan juga wirausaha kuliner dan (15) $\mathrm{T}$ seorang wirausaha kuliner. Semua narasumber di atas memiliki UMKM dengan kategori mikro dan kecil, kecuali usaha ST yang termasuk menengah.

Dari limabelas narasumber pemilik UMKM, semuanya belum ada yang mencatat transaksi ekonomi secara sistematis dan terpadu berdasarkan standar akuntansi. Namun demikian, mereka sudah menjalankan pencatatan akuntansi yang sederhana seperti tabelaris untuk kas masuk, kas keluar, hasil penjualan, stok barang dan daftar hutang dan piutang. Seperti dikatakan oleh D:

pencatatan berupa kas keluar-masuk. Adajuga laba-rugi, tetapi tidak rutin, paling bulanan atau tahunan....kalau aset atau hutang belum dicatat secara detail, seperti aset cair, aset bergerak atau tidak bergerak, itu tidak ada.

Hal yang sama diungkapkan oleh ST:

sudah ada pencatatan pendapatan dan pengeluaran, namun masih manual, hanya tulis di buku saja. 
dan juga A:

Tidak ada pembukuan yang resmi, ya paling pembukuuannya bon, tagihan.

Sedangkan RB sudah mencatat penjualan dengan Excel secara harian,

Saya melakukan pencatatan di Ms. Excel dari laporan harian penghasilan

yang saya terima dari manajer pengelola.

Dan LG hanya mencatat saja atas pengiriman dan penjualan, tapi tidak secara spesifik mencatat piutang

Hanya mencatat barang yang dikirim dan kas yang diterima, tidak menyusun laporan keuangan. Saya mencatatnya dengan membedakan pencatatan setiap kantin..... Ada juga yang belum bayar, kalau masih belum bayar tinggal tulis saja 'belum bayar'. Tidak membuat notes lagi. Dalam satu kertas itu aja.

Beberapa narasumber bisa menyusun laporan laba rugi saja yang sederhana, namun tidak untuk laporan posisi keuangan. Y mengatakan:

belum bisa membuat laporan keuangan yang seperti di perusahaan-perusahaan besar. Saya ada laporan laba rugi, tapi masih sederhana, hanya hasil penjualan dan biaya yang saya keluarkan. Belum ada depresiasi.

Demikian juga dengan YD

Saya hitung keuntungan dan arus kas. Karena menjual soto maka pembayaran secara kas, jadi tidak ada catatan piutangnya. Kalaupun pakai Grabfood pembayaran kas diterima esok harinya.

SH mengatakan:

Laporan laba rugi saya ada. Tapi ya sederhana saja berupa catatan untuk mengetahui untungnya berapa.

Selain laporan laba rugi, beberapa narasumber menyatakan bahwa laporan kas merupakan laporan yang penting. Laporan kas yang dimaksudkan adalah informasi jumlah kas masuk dan keluar. Y menyatakan:

Menurut saya informasi saldo kas yang paling penting karena dengan tahu kasnya berapa, saya bisa merencanakan untuk menyisihkan sejumlah uang tertentu untuk membeli peralatan.

Demikian juga dengan SH yang mengatakan:

Dari catatan kas ini, saya bisa tahu masih ada dana tidak untuk membeli bahan untuk membuat produk kerajinan.

Hal menarik yang didapat dari penelitian ini adalah, pelaku UMKM yang menjual produknya lewat E-Commerce, terbantu dalam hal pencatatan jumlah penjualan dan kas karena mereka secara langsung mendapat informasi tentang hal tersebut dari platform ECommerce. YD mengatakan:

Di GOBiz, Grabmerchant, OVOmerchant sudah ada laporan penerimaan kas...dari situ saya sudah punya catatan hasil penjualan

Demikian juga dengan YE,

Saya jualan tas lewat Tokopedia, Shopee dan Lazada, jadi kalau ada yang terjual, uangnya sudah langsung masuk ke akun saya. Namun, saya juga banyak tergoda untuk belanja keperluan saya dan anak saya dengan langsung memakai saldo uangnya itu.

Dengan demikian, pemakaian dompet digital membutuhkan kedisplinan bagi pelaku UMKM untuk menerapkan pemisahan harta bisnis dan pribadi. mengatakan

Keutamaan pemakaian akun bank dalam mengontrol kas dialami oleh RV yang

Saya menggunakan Instagram untuk mempromosikan produk makanan dan omong-omong dengan pelanggan untuk menjual di Whatapp. Kemudian pelanggan membayar lewat E-Banking. Jadi uangnya langsung masuk rekening 
bank. Saya tinggal mencocokkan kas yang diterima melalui bank dengan catatan jumlah penjualan.

Penelitian ini menemukan belum ada pelaku UMKM yang menggunakan aplikasi sistem informasi akuntansi berbasis android untuk pencatatan transaksi. Y mengatakan

Saya tahu aplikasi itu dan pernah mencoba, tapi bingung cara memakainya.

Saya saja yang punya latar belakang akuntansi saja bingung, apalagi temanteman lain yang tidak punya pengetahuan akuntansi.

Juga YE yang mempunyai pengalaman terkait penggunaan aplikasi akuntansi di Android.

Pernah memakai satu aplikasi di handphone untuk mencatat, tapi saya tidak begitu paham mengoperasionalkan aplikasi tersebut dan pemakaiannya tidak praktis karena ketika handphone ke reset semua data yang ada di aplikasi tersebut hilang.

Narasumber pemilik UMKM lainnya malah belum melaksanakan catatan akuntansi. T mengatakan

Saya tidak punya pencatatan, karena uang hasil penjualan langsung dipakai belanja buat keperluan keluarga

Demikian DA juga mengatakan

Belum ada laporan keuangan, karena kita dikelola keluarga sendiri

Dan NM yang menyatakan

Usaha menjahit saya murni modal tabungan saya, suami saya juga tidak tahu.

Jahitan saya juga sedikit jadi ya saya tidak menghitung untungnya berapa.

Sekarang pesanan jahitan sudah banyak dan menurut saya sudah harus mulai buat pembukuan ya.

Hal menarik dikatakan oleh LG terkait pencatatan akuntansi di saat pandemic, yaitu Kalau untuk sebelum pandemi ya ada catatannya. Tapi kalau sekarang pandemi seperti ini hanya receh-receh tidak dicatat ya karena langsung kepakai.

Alasan lain tidak diimplementasikannya akuntansi di UMKM adalah masih banyak pelaku UMKM yang belum memisahkan antara harta usaha dan pribadi. T menyatakan: seperti halnya saya dan teman-teman lainnya banyak yang belum membedakan harta pribadi dan usaha. Jadi masih campur aduk.

Demikian juga yang dikatakan Y, yaitu

Masih banyak teman-teman lain yang belum paham tentang akuntansi dan pentingnya akuntansi. Saya ajak mereka dengan melakukan pelatihan.

Berdasarkan analisis data hasil wawancara dengan narasumber yang memiliki catatan akuntansi, penelitian ini menemukan bahwa pengetahuan dan pengalaman merupakan jalan masuk institusi akuntansi di UMKM. Dengan memiliki dua hal tersebut, mereka timbul kesadaran bahwa akuntansi dapat membantu dalam mengelola keuangan sehingga usaha bisa lebih berkembang lagi. Seperti dikatakan oleh YD, yaitu

Karena saya punya latar belakang akuntansi dan kerja sebagai auditor, saya paham tentang harga pokok produksi.

Demikian juga dengan Y,

Sebelum saya mulai usaha, saya kerja di perusahaan dengan posisi terkahir sebagai Vice President. Jadi saya tahu cara mengelola organisasi. Itu saya terapkan dalam menjalankan bisnis saya, seperti memisahkan harta pribadi dan harta usaha dari awal. Kemudian saya catat semua pengeluaran mulai dari beli bahan dan peralatan, mengurus paten dan mengurus sertifikat halal.

Selain itu, pelaku UMKM menyadari untuk mengimplementasikan praktik akuntansi setelah mendapat pelatihan manajemen keuangan secara informal. Seperti yang dikatakan oleh S, yaitu 
Saya tahunya bagaimana menentukan harga pokok snack yang saya buat dari pelatihan dari Ibu Y. Dari harga pokok ini, saya bisa menentukan harga jualnya.

Demikian juga YD

Saya diajak oleh Ibu Y...meskipun saya bekerja di perusahaan, saya tidak tahu bagaimana akuntansi untuk kuliner...jadi saya ikut pelatihan.

Sedangkan YE menceritakan pengalamannya

Saya ikut pelatihan dari program BRI Inkubator, disana saya diajari menghitung ongkos produksi. Saya disuruh menghitung sampai detail-detail pengeluaran yang dulunya tidak pernah saya perhitungkan untuk menentukan harga pokok tas.

SH mempunyai pengalaman yang agak berbeda dengan komunitasnya, yaitu

Di komunitas kami, tidak hanya pelatihan tentang akuntansi, tapi ada juga pelatihan untuk membuat jenis kerajinan yang inovatif dan komunitas kami juga membantu dalam hal keuangan dan pemodalan. Saat ini kami proses mendirikan koperasi untuk menunjang pemodalan.

Adanya manfaat dari akuntansi juga dinyatakan oleh narasumber pemilik UMKM yang telah melakukannya. Manfaat pertama adalah akuntansi untuk melindungi aset. LD menyatakan

dari pencatatan itu kita bisa tahu masih ada piutang yang belum dibayar

Lain halnya pengalaman RB

karena kalau kami tidak catat artinya kami benar-benar tidak tahu mengenai usaha kami sendiri, apakah mungkin kami dibohongi atau tidak oleh manajer pengelola.

Manfaat kedua adalah untuk menilai pencapaian kinerja usahanya. Seperti yang dikatakan oleh LG

Manfaatnya itu, pertama saya jadi tahu penjualan rata-rata di setiap kantin sehingga saya bisa mengestimasi keperluan untuk berikutnya. Manfaat kedua, membuat saya punya gambaran mengenai omset yang akan saya peroleh. Terakhir, manfaat pencatatan itu ya untuk mengingatkan sekaligus menjadi bukti adanya piutang-piutang yang masih belum dibayar.

Manfaat ketiga adalah akuntansi digunakan untuk merencanakan perkembangan

bisnis. NC memakai catatan akuntansi untuk pengambilan keputusan dalam menilai manakah pihak konveksi yang lebih murah, antara konveksi lama atau baru.

Lain halnya yang diungkapkan oleh RB

kami jadi tahu detail mengenai adanya peningkatan usaha atau tidak, lalu apa saja biaya-biaya tetap maupun biaya-biaya tak terduga, jadi kami bisa membagi keuangan di awal tahun

Dan Y mempunyai pengalaman yang berbeda, yaitu dari catatan kas masuk dan keluar, saya bisa merencanakan untuk menyisihkan sejumlah uang tertentu yang digunakan untuk membeli peralatan, mengikuti pelatihan tentang bisnis halal dan mengurus perijinan dan hak paten.

Sedangkan SH mengatakan

Karena ini kan bisnis kerajinan, jika tidak ada inovasi maka orang akan bosan sehingga harus banyak berkreasi. Saya mengelola kas supaya mempunyai uang untuk berinovasi agar menghasilkan kerajinan tangan yang kekinian.

$\mathrm{S}$ juga mempunyai pengalaman

Usaha saya masih sangat kecil, jadi Ketika saya melihat berapa jumlah uang yang bisa saya kumpulkan dari usaha, maka saya punya rasa bangga dan termotivasi untuk tetap mengembangkan usaha. 
Manfaat keempat adalah laporan keuangan digunakan untuk mengajukan pinjaman ke Lembaga keuangan. ST mengatakan

Dulu pernah mengajukan pinjaman dan waktu itu dibutuhkan laporan penjualan dan pengeluaran

dan A mempunyai pengalaman

Pernah mengajukan pinjaman dan diminta bon penjualan, pendapatan, pengeluaran jangka waktu 3 bulan

Manfaat kelima adalah laporan akuntansi untuk transparansi dan pertanggungjawaban. NC mengatakan

Manfaatnya ya untuk transparansi, karena ini kan bisnis berdua bersama teman, jadi ya biar sama-sama enak lah antara kedua owner ini.

Demikian juga D yang menyatakan bahwa catatan akuntansi

menjadi landasan dalam perhitungan pembagian hasil. Tapi pencacatan ini bukan untuk dilaporkan ya, tetapi lebih sebagai bentuk transparansi.

Sedangkan hal yang menarik diungkapkan oleh Y

Dari awal keluarga meragukan usaha saya, ternyata saya baru sadar dari laporan laba rugi yang saya buat seadanya bisa menyakinkan keluarga untuk percaya kalua usaha saya bisa diandalkan untuk memenuhi kebutuhan keluarga.

Manfaat keenam adalah akuntansi digunakan untuk efisiensi biaya produksi. Hal ini dijelaskan oleh YE

Dari pelatihan yang saya ikuti, saya jadi tahu bahwa bahan baku pembuatan tas harus dicatat. Dulu saya tidak memperhitungkan bahan baku seperti kancing, benang, zipper, lem. Dengan mencatat dan menghitung, saya jadi tahu bahwa, misalnya untuk satu tabung lem bisa untuk produksi berapa tas atau misalnya produksi 12 tas jangan sampai menghabiskan zipper 24.

Demikianlah hasil wawancara dengan limabelas narasumber pelaku UMKM tentang interaksi mereka dengan institusi akuntansi. Berikutnya adalah analisa dengan kerangka teori Hopwood (2013) untuk menjelaskan bagaimana dinamika interaksi antara institusi akuntansi dan latar belakang sosial dan ekonomi pelaku UMKM dengan bisnisnya.

Penelitian ini menemukan bahwa interaksi institusi akuntansi dan faktor sosial dalam implementasi akuntansi di UMKM belum dinamis dan maksimal. Jangankan praktik akuntansi yang sesuai dengan standar, pencatatan akuntansi double entry juga belum dilakukan oleh UMKM dan bahkan ada UMKM yang tidak menerapkan akuntansi.

Standar akuntansi belum merupakan hal yang umum bagi UMKM. Bahkan pemilik UMKM yang berpendidikan sarjana ekonomi juga belum menerapkan standar akuntansi dalam pencatatan. Hal ini bertentangan dengan hasil penelitian sebelumnya yang menyatakan bahwa keterbatasan pengetahuan menyebabkan praktik akuntansi yang berdasarkan standar tidak bisa dilaksanakan (Kurniawati et al., 2012; Niode, 2009; Nwobu et al., 2015; Pulakanam \& Suraweera, 2010; Savitri \& Saifudin, 2018; Sibanda \& Manda, 2016). Dalam penelitian ini narasumber Y, YD, RV, RB, D, NC dan LG yang merupakan lulusan sarjana akuntansi/manajemen dan mengetahui tentang standar akuntansi juga belum melaksanakan praktik akuntansi berdasarkan standar yang berlaku.

Akuntansi dilaksanakan oleh UMKM dengan system pencatatan pembukuan tunggal. Penelitian ini mengasumsikan bahwa pencatatan double entry membutuhkan usaha dan waktu yang banyak namun tidak seimbang dengan ukuran UMKM yang masih mikro dan kecil. Sebagian besar kondisi bisnis narasumber masih dalam tahap awal perkembangan bisnisnya yang ditunjukkan dengan omzet dan modal bisnis yang terbatas dan tanpa pinjaman, pengelolaan usaha terbatas keluarga saja dan uang hasil penjualan untuk menopang kebutuhan keluarga. Kondisi bisnis yang masih mikro dan kecil inilah yang paling mungkin menjadi penghalang utama dalam implementasi standar akuntansi EMKM. 
Semua UMKM yang dijadikan contoh kasus belum mengetahui adanya SAK EMKM, walaupun sampai dengan penelitian ini dilaksanakan SAK EMKM sudah empat tahun disahkan. Keadaan ini mengidentifikasikan bahwa institusi akuntansi untuk UMKM yang dibangun oleh asosiasi profesi belum terhubung secara optimal dengan praktik akuntansi yang terjadi saat ini diantara pelaku UMKM. Mungkin ke depannya perwakilan dari lembaga profesi akuntan ini harus melakukan sosialisasi SAK EMKM dengan jangkauan daerah yang lebih luas.

Hal menarik lainnya yang ditemukan oleh penelitian ini adalah adanya sistem informasi akuntansi sebagai salah satu jenis institusi akuntansi, belum banyak diterapkan oleh UMKM. Mereka banyak mencatat lewat manual buku dan menghitung lewat Excel. Aplikasi akuntansi di Android belum banyak dikenal.

Dari hasil penelahaan, penelitian ini melihat bahwa akuntansi sulit masuk ke lembaga UMKM juga karena faktor hukum dan sosial. Secara hukum, belum ada peraturan undangundang yang mewajibkan UMKM untuk menyusun laporan keuangan sesuai dengan standar akuntansi. Undang-undang UMKM yang diatur oleh negara tidak memuat pernyataan langsung bahwa UMKM harus tunduk pada standar akuntansi. Sedangkan secara sosial, banyak UMKM yang tidak terhubung dengan lembaga pendanaan formal seperti bank sehingga tidak ada keharusan bagi mereka untuk menyusun laporan keuangan. Jika UMKM mengajukan kredit ke bank, maka mereka akan termotivasi untuk menyusun laporan keuangan sesuai dengan standar dimana hal ini merupakan ketentuan dari bank. Kondisi hukum dan sosial inilah yang juga menjadi penyebab akuntansi masih belum terinstitusi dengan baik di UMKM.

Meskipun institusi akuntansi berupa standar dan sistem informasi belum diaplikasikan secara maksimal oleh UMKM, sebagian besar mereka sudah sadar akan manfaat akuntansi dan mau menerapkannya di masa mendatang. Penelitian ini memandang praktik akuntansi buku tunggal yang diterapkan oleh UMKM merupakan refleksi kebutuhan mereka dalam menjalankan bisnisnya. Praktek tersebut sesuai dengan yang kondisi bisnis UMKM yang masih dalam tahap awal perkembangan. Mereka membutuhkan akuntansi hanya untuk menghitung jumlah kas, menentukan harga pokok produksi dan menghitung keuntungan.

Namun, penelitian ini menyakini bahwa walaupun akuntansi yang diterapkan itu belum sepenuhnya sesuai dengan peraturan, pelaku UMKM secara sukarela menerapkan akuntansi tanpa tekanan dari pihak luar. Mereka dengan kemauan sendiri, bersedia menerapkan teknik akuntansi yang dirasakan membawa faedah ekonomi dan sosial bagi mereka. Artinya, rasionalitas praktik akuntansi yang terjadi tergantung dari apa yang dialami oleh pelaku UMKM dan penerapan akuntansi oleh mereka bukan sekedar seremoni, namun merupakan kebutuhan (DiMaggio \& Powell, 1983; Hines, 1989)

Penelitian ini membuktikan konsep Burchell et al. (2013) dan Potter (2005) bahwa melalui implementasi teknik akuntansi akan menciptakan kondisi dimana akuntansi sebagai teknologi sekaligus juga sebagai alat untuk melakukan intervensi agar transformasi realitas ekonomi dan sosial terjadi diantara pelaku akuntansi. Manfaat yang mereka rasakan dari implementasi akuntansi, seperti kondisi yang sebelumnya belum mampu menghitung keuntungan dengan benar menjadi bisa menghitung, dulunya belum bisa menghitung ongkos produksi kemudian mampu melakukan penghematan ongkos produksi, dari yang dulu belum mampu menyisihkan kas sekarang menjadi lebih disiplin dalam menyisihkan kas hasil penjualan untuk perkembangan bisnis, merupakan bentuk perubahan positif atas kondisi sosial dan ekonomi yang mereka alami dari penerapan teknologi akuntansi.

Mengacu pada Burchell et al. (2013) dan Potter (2005) juga, penelitian ini menemukan bahwa alasan rasional atas manfaat akuntansi merupakan dasar untuk memilih teknik akuntansi yang digunakan. Narasumber dalam penelitian ini semua memakai akuntansi sistem buku tunggal dan mereka belum pindah ke sistem double entry. Penelitian ini melihat 
penerapan seperti ini menunjukkan rasional pelaku UMKM terhadap akuntansi masih ada di sistem buku tunggal karena sudah mendapat manfaat ekonomi dan sosial dari sistem buku tunggal tersebut. Dengan demikian, institusi akuntansi sistem buku tunggal sudah secara sosial meresap dalam mereka.

Kondisi tersebut bukan kondisi yang buruk, karena kondisi tersebut menunjukkan mereka sudah mengenal dan menyadari manfaat akuntansi dengan sistem buku tunggal dan hal ini cukup ideal untuk mengenalkan standar akuntansi dengan sistem double entry. Hal ini sesuai dengan pendapat Hopwood (2013) dan Potter (2005) yaitu penerapan teknik akuntansi tertentu lebih mudah diimplementasikan dengan kondisi sosial tertentu. Dalam penelitian ini, kondisi pelaku UMKM sudah merasakan manfaat akuntansi untuk bisnisnya akan mempermudah mereka dalam menerima SAK EMKM sehingga dapat mengurangi resistansi terhadap penerapan SAK EMKM.

\section{SIMPULAN, KETERBATASAN DAN SARAN \\ Simpulan}

Penelitian ini menemukan penghalang dalam implementasi akuntansi di UMKM yaitu belum optimalnya dinamika interaksi institusi akuntansi dan faktor sosial. Temuan ini menjadi pelengkap untuk penelitian sebelumnya (Purwati, Suparlinah, and Putri 2014; Sibanda and Manda 2016; Nwobu, Faboyede, and Onwuelingo 2015; Pulakanam and Suraweera 2010; Sibanda and Manda 2016). Selain itu penelitian ini berhasil membuktikan konsep Burchell et al. (2013) dan Potter (2005) bahwa implementasi teknologi akuntansi merupakan alat untuk mengubah perilaku pelaku UMKM secara ekonomi dan sosial dalam mengembangkan bisnisnya. Penelitian ini juga menyimpulkan bahwa rasional atas manfaat akuntansi yang disesuaikan dengan kondisi bisnis merupakan dasar untuk menerapkan sistem pencatatan akuntansi tertentu.

Untuk memperkenalkan SAK EMKM kepada UMKM, diperlukan program yang solid guna menjembatani asosiasi profesi dengan UMKM. Program tersebut bisa dilakukan melalui kerja sama antara asosiasi profesi atau perguruan tinggi dengan komunitas UMKM untuk melakukan sosialisasi, pelatihan dan workshop.

\section{Keterbatasan}

Penelitian ini diselenggarakan dimasa pandemic COVID-19, sehingga wawancara dilakukan secara jarak jauh sehingga terhambat oleh sinyal. Namun dengan wawanacara jarak jauh, peneliti dapat menjangkau daerah yang lebih luas. Jumlah narasumber masih sedikit dan belum mewakili UMKM di Indonesia, karena banyak pelaku UMKM yang tidak merespon permintaan peneliti untuk melakukan wawancara dengan alasan kondisi ekonomi yang lesu.

\section{Saran Untuk Penelitian Selanjutnya}

Hasil penelitian ini yang menemukan bahwa institusi akuntansi belum masuk secara optimal di sebagian besar UMKM. Oleh karena itu, penelitian lebih lanjut sebaiknya fokus tentang bagaimana proses institusi akuntansi yang sesuai dengan SAK EMKM dapat secara sukses diimplementasikan oleh UMKM.

\section{DAFTAR PUSTAKA}

Badan Pusat Statistik. (2019). Perkembangan Indeks Produksi Triwulanan Industri Mikro dan Kecil Tahun 2017-2019.

DiMaggio, P. J., \& Powell, W. W. (1983). The Iron Cage Revisited: Institutional Isomorphism and Collective Rationality in Organizational Fields. American Sociological Review, 48(2), 147. https://doi.org/10.2307/2095101 
Hines, R. D. (1989). Financial Accounting Knowledge, Conceptual Framework Projects and the Social Construction of the Accounting Profession. Accounting, Auditing \& Accountability Journal, Vol. 2(Issue: 2).

Hopwood, A. G. (2013). On trying to study accounting in the contexts in which it operates. Accounting From the Outside (RLE Accounting): The Collected Papers of Anthony G. Hopwood, 8(213), 159-177.

International Trade Centre. (2021). Empowering the Green Recovery.

Kementerian Keuangan Republik. (2021). Pemerintah Terus Perkuat UMKM Melalui Berbagai Bentuk Bantuan. 27 September. https://www.kemenkeu.go.id/publikasi/berita/pemerintah-terus-perkuat-umkmmelalui-berbagai-bentuk-bantuan/

Kementerian Koperasi dan UMKM. (2017). Perkembangan Data Usaha Mikro, Kecil, Menengah (UMKM) Dan Usaha Besar (Ub) Tahun 2016 - 2017. http://www.depkop.go.id/Uploads/Laporan/1549946778_Umkm 2016-2017 rev.Pdf

Kurniawati, E. P., Nugroho, P. I., \& Arifin, C. (2012). Penerapan Akuntansi Pada Usaha Mikro Kecil Dan Menengah (UMKM). Jurnal Manajemen Dan Keuangan, 10(2). https://doi.org/10.31294/jabdimas.v2i2.5818

Niode, I. Y. (2009). Sektor UMKM Di Indonesia: Jurnal Kajian Ekonomi Dan Bisnis OIKOS-NOMOS, 2(1).

Nwobu, O., Faboyede, S. O., \& Onwuelingo, A. T. (2015). The role of accounting services in small and medium scale businesses in Nigeria. Journal of Accounting, Business \& Management, 22(1), 55-63.

Pemerintah Republik Indonesia. (1993). Keputusan Presiden Republik Indonesia Nomor 58 Tahun 1993 Tentang Perubahan Atas Keputusan Presiden Nomor 15 Tahun 1984 Tentang Susunan Organisasi Departemen Sebagaimana Telah Delapan Belas Kali Diubah, Terakhir Dengan Keputusan Presiden Nomor 67 Tahun 1992.

Pemerintah Republik Indonesia. (1995). Undang-Undang Republik Indonesia Nomor 9 Tahun 1995 Tentang Usaha Kecil.

Pemerintah Republik Indonesia. (1998). Ketetapan Majelis Permusyawaratan Rakyat Republik Indonesia Nomor XVI/MPR/1998 Tentang Politik Ekonomi Dalam Rangka Demokrasi Ekonomi.

Pemerintah Republik Indonesia. (2008). Undang-Undang Republik Indonesia Nomor 20 Tahun 2008 Tentang Usaha Mikro, Kecil, Dan Menengah.

Pulakanam, V., \& Suraweera, T. (2010). Implementing Accounting Software in Small Businesses in New Zealand: an Exploratory Investigation. Accountancy Business and the Public Interest, 9(64), 98-124.

Savitri, R. V., \& Saifudin, . . (2018). Pencatatan Akuntansi Pada Usaha Mikro Kecil Dan Menengah (Studi Pada Umkm Mr. Pelangi Semarang). JMBI UNSRAT (Jurnal Ilmiah Manajemen Bisnis Dan Inovasi Universitas Sam Ratulangi)., 5(2), 117-125. https://doi.org/10.35794/jmbi.v5i2.20808

Sibanda, J. J., \& Manda, D. C. (2016). Symptoms of accounting practices that contribute to small business failures in South Africa. Problems and Perspectives in Management, 14(4), 194-202. https://doi.org/10.21511/ppm.14(4-1).2016.08 